\title{
Full-length infectious clone of a low passage dengue virus serotype 2 from Brazil
}

\author{
Jefferson José da Silva Santos, Tereza Magalhães', José Valter Joaquim Silva Junior', \\ Andréa Nazaré Monteiro Rangel da Silva1, Marli Tenório Cordeiro ${ }^{1,2}$, Laura Helena Vega Gonzales Gil1/++
}

${ }^{1}$ Fundação Oswaldo Cruz, Centro de Pesquisas Aggeu Magalhães, Laboratório de Virologia e Terapia Experimental, Recife, PE, Brasil ${ }^{2}$ Departamento de Saúde do Estado de Pernambuco, Laboratório Central de Saúde Pública, Recife, PE, Brasil

Full-length dengue virus (DENV) cDNA clones are an invaluable tool for many studies, including those on the development of attenuated or chimeric vaccines and on host-virus interactions. Furthermore, the importance of low passage DENV infectious clones should be highlighted, as these may harbour critical and unique strain-specific viral components from field-circulating isolates. The successful construction of a functional Brazilian low passage DENV serotype 2 full-length clone through homologous recombination reported here supports the use of a strategy that has been shown to be highly useful by our group for the development of flavivirus infectious clones and replicons.

Key words: infectious clone - yeast homologous recombination - flavivirus

Dengue is an arthropod-borne disease found in tropical and subtropical regions throughout the world. The incidence of dengue has increased significantly in the past years and a recent study estimates that 390 million people are infected with dengue viruses (DENV) annually (2013). In the Americas, Brazil and Mexico account for most cases (Bhatt et al. 2013). The burden of dengue is due to the mortality rate (which can reach approximately $5 \%$ of the severe cases) and to the morbidity rate among symptomatic patients, which involves a broad spectrum of symptoms and may last for several days. In fact, the classification of dengue clinical cases remains a complex and changing subject (Horstick et al. 2015). Although there are currently a few vaccine formulations in clinical trials, there are no licensed vaccines available against DENV (Ishikawa et al. 2014). The complex interactions among hosts (humans and mosquitoes) and different virus strains most likely represent part of the obstacle to the development of an effective vaccine.

DENV (genus Flavivirus, family Flaviviridae) are transmitted to humans by female adult mosquitoes, with Aedes aegypti being the most important vector (Nene et al. 2007). There are four recognised DENV serotypes (DENV1-DENV4), with multiple genotypes/lineages identified within each serotype (Chen \& Vasilakis 2011). The importance of viral genotype/lineage identification is due to strain-associated features involved in viral repli-

doi: 10.1590/0074-02760150053

Financial support: FIOCRUZ (PAPES V), CNPq (CNPq-470892/2007-2) JJSS currently address: University of Maryland, Department of Veterinary Medicine, College Park, MD, USA

+Corresponding author: laura@cpqam.fiocruz.br

Received 9 February 2015

Accepted 11 June 2015 cation and pathogenesis (Rico-Hesse 2007). The genome of DENV consists of positive single-stranded RNA and is approximately $10.7 \mathrm{~Kb}$ with a 5' cap structure and a 3' untranslated region that lacks a poly (A) tail. A polyprotein is encoded by a single open reading frame within the genome and it is further cleaved into three structural and seven nonstructural (NS) proteins $\left(\mathrm{NH}_{2}-\mathrm{C}-\mathrm{prM}-\mathrm{E}-\right.$ NS1-NS2A-NS2B-NS3-NS4A-NS4B-NS5-COOH) by viral and host proteases (Chambers et al. 1990).

A full-length complementary DNA (cDNA) clone or infectious clone of a virus is a powerful tool that allows for the manipulation of the viral genome for various purposes, providing a homogeneous viral population for research (Ruggli \& Rice 1999). Although not all infectious clones rely on in vitro transcription or cloning vectors, to simplify, here we will consider full-length clones that consist of the whole viral genome inserted in a cloning vector downstream of the sequence of an RNA polymerase phage promoter. The construct is then propagated in a bacteria or yeast host, linearised and in vitro transcribed to generate transcripts that resemble the parental virus genome. The transcripts are further used to transfect cells, allowing for the production of mature virions. Fulllength flavivirus infectious clones have been reported since 1991 (Lai et al. 1991). However, the major obstacle for these studies is the instability of the viral genome in host systems, especially in Escherichia coli (Ruggli \& Rice 1999). Different methodologies have been applied to overcome viral genome instability, including the use of low copy bacterial plasmids and bacterial artificial chromosome (BAC) vectors.

Homologous recombination in yeast with linear DNA fragments containing homologous regions in their ends can overcome laborious cloning strategies in bacteria (Gibson 2009). Importantly, with regard to the construction of flavivirus infectious clones, this technique yields more stable plasmid amplification than in bacteria, as it has been shown that the genome of some flaviviruses, such as DENV, may contain cryptic bacterial promoters. These promoters lead to the unwanted production of vi- 

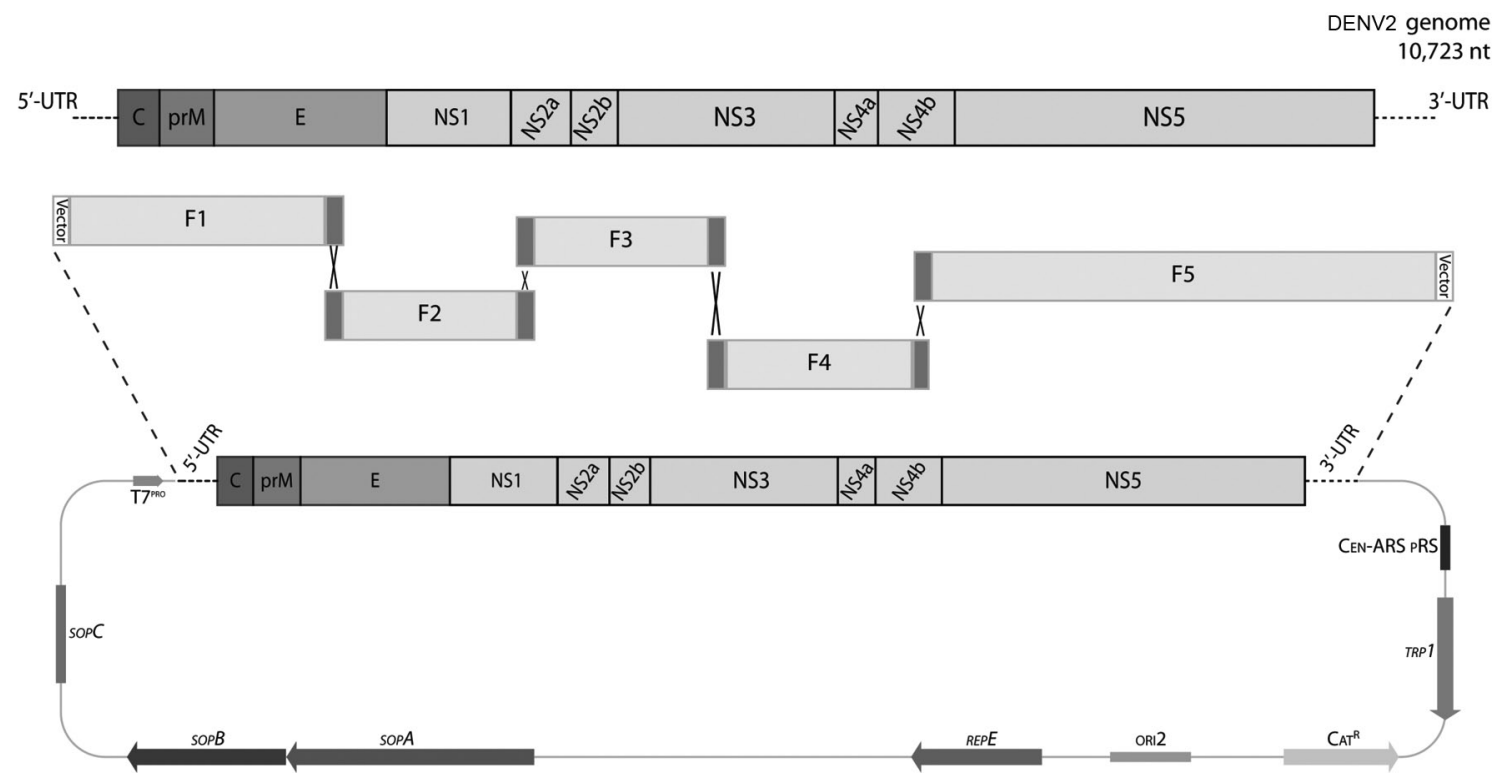

Fig. 1: construction of a low passage full-length dengue virus serotype 2 (DENV2) infectious clone named pSVJS01-DENV2. Five fragments within the DENV2 genome were amplified and inserted into the shuttle vector pSVJS01 through homologous recombination in yeast. E: envelop; F: fragment; NS: nonstructural; UTR: untranslated region.

ral proteins/regions that are toxic to the bacteria $(\mathrm{Pu}$ et al. 2011), which results in viral genome modifications (e.g., deletions, insertions) during the amplification process.

In the present paper, we report the construction of a full-length DENV2 infectious clone based on a low passage clinical isolate, through homologous recombination in yeast. The virus DENV2 BR-3808 was isolated from a biological sample collected from a patient presenting with dengue fever during a dengue outbreak in Recife, state of Pernambuco, Brazil, in 1995. An aliquot of the biological sample was inoculated into $\mathrm{C} 6 / 36$ mosquito cells and, after a few days, the flask content was harvested for virus identification through reverse transcription-polymerase chain reaction (RT-PCR) using primers specific for DENV2 (Lanciotti et al. 1992) and indirect immunofluorescence (IFA). The virus was then cultured in $\mathrm{C} 6 / 36$ until passage $3 . \mathrm{C} 6 / 36$ were maintained at $28^{\circ} \mathrm{C}$ in Leibovitz's medium (L15) containing 5\% foetal bovine serum (FBS), 1\% antibiotics solution (stock solution at 10,000 units $/ \mathrm{mL}$ of penicillin and $10,000 \mu \mathrm{g} / \mathrm{mL}$ of streptomycin) and $0.1 \%$ Fungizone (stock solution at $250 \mu \mathrm{g} /$ $\mathrm{mL}$ ). Next, DENV2 BR-3808 was plaque purified and amplified once in baby hamster kidney (BHK)-21 cells. BHK-21 was maintained at $37^{\circ} \mathrm{C}$ in a $5 \% \mathrm{CO}_{2}$ incubator in minimum essential medium (MEM) supplemented with $10 \%$ FBS, $1 \%$ antibiotics solution and $0.1 \%$ Fungizone.

Construction of the DENV2 infectious clone was performed using the same strategy described previously by our group for the construction of a DENV3 full-length clone (Santos et al. 2013). Electrocompetent E. coli DH10B and Saccharomyces cerevisiae YPH252 were used for plasmid amplification. S. cerevisiae RFY206 was used for homologous recombination to insert the DENV2 genome into a shuttle vector previously constructed, pSVJS01 (Santos et al. 2013). This plasmid is a modified version of the BAC vector pBeloBAC11, into which a $2 \mathrm{~kb}$ fragment of the plasmid pRS414 (that allows replication and selection in yeast), a T7 promoter recognition site and a multiple cloning site was inserted. This construct ensures amplification at low copy number in yeast, a strategy known to minimise infectious clone instability (Bredenbeek et al. 2003, Suzuki et al. 2007). The DENV2 infectious clone was constructed as shown in Fig. 1. Firstly, the viral genome was amplified in five overlapping fragments. Primers sequences and fragment size are depicted in Table I. Primer PSVJS01-F contained an RsrII restriction site, a T7 promoter recognition site and an additional $\mathrm{G}$ immediately before the first base of the DENV2 genome. Amplified fragments (F1F5) were assembled into the NotI-linearised pSVJS01 vector by homologous recombination in the YPH 252 yeast strain. The DENV2 full-length infectious clone, named pSVJS01-DENV2, was successfully assembled by this strategy. The full-length PCR amplicon from two pSVJS01-DENV2 clones (3 and 10) was confirmed by gel electrophoresis. Functional clones were maintained in yeast to prevent infectious clone instability that may occur upon amplification in bacteria (Polo et al. 1997, Ruggli \& Rice 1999). PCR amplicons derived from pSVJS01-DENV2 were purified using phenol-chloroform extraction and ethanol precipitation and the purified amplicons were used as a template for full-length in vitro RNA transcription. For transcription, the MEGAScript T7 kit (Ambion) was used with the addition of a 7-methyl-guanosine cap analogue (Ambion), following the manufacturer's instructions. Transcript analysis through formaldehyde-agarose gel electrophoresis showed highquality products (data now shown). RNA transcripts 


\section{TABLE I}

Primers used to amplify fragments of the dengue virus serotype 2 (DENV2) (strain BR-3808) genome used to assemble the full-length infectious clone through homologous recombination in yeast

\begin{tabular}{|c|c|c|c|c|c|}
\hline \multirow[b]{2}{*}{ Fragment } & \multirow[b]{2}{*}{ Primer } & \multirow[b]{2}{*}{$\begin{array}{l}\text { Sequence } \\
\left(5^{\prime}-3{ }^{\prime}\right)\end{array}$} & \multirow[b]{2}{*}{$\begin{array}{l}\text { Amplicon } \\
\text { size } \\
\text { (bp) }\end{array}$} & \multicolumn{2}{|c|}{ Primer annealing } \\
\hline & & & & $\begin{array}{c}\text { Position } \\
\quad(\mathrm{nt})^{a}\end{array}$ & $\begin{array}{l}\text { Gene } \\
\text { region }\end{array}$ \\
\hline \multirow[t]{2}{*}{$\mathrm{F} 1$} & PSVJS01-F & 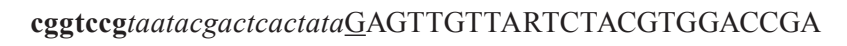 & 2,045 & $1-23$ & 5'-UTR \\
\hline & DENV2-2045-R & TCTGCTTCTATGTTGACTGGG & & $2,025-2,045$ & $\mathrm{E}$ \\
\hline \multirow[t]{2}{*}{ F2 } & DENV2-1810-F & CTACAGCTCAAAGGAATGTCAT & 1,760 & $1,810-1,831$ & $\mathrm{E}$ \\
\hline & DENV2-3570-R & CATGTTTCGTTCCTACTCGGGTCC & & $3,548-3,571$ & NS2A \\
\hline \multirow[t]{2}{*}{ F3 } & DENV2-3501-F & TCACTAGGAGTCTTGGGAATGGC & 2,058 & $3,502-3,524$ & $\mathrm{NS} 2 \mathrm{~A}$ \\
\hline & DENV2-5559-R & TCCGTGACCCATTCATGTCC & & $5,560-5,579$ & NS3 \\
\hline \multirow[t]{2}{*}{$\mathrm{F} 4$} & DENV2-5491-F & CATTTCCTCAGAGCAATGCACCAATC & 1,878 & $5,492-5,517$ & NS3 \\
\hline & DENV2-7369-R & AATACTTGAGTCACGCAGAGG & & $7,350-7,370$ & NS4a \\
\hline \multirow[t]{2}{*}{ F5 } & DENV2-7190-F & GCCAGGACTTCAAGCAAAAGC & 3,533 & $7,191-7,211$ & $\mathrm{NS} 4 \mathrm{a}$ \\
\hline & PSVJS01-R & ttcaacatttcegtgtcgegcggecgcAGAACCRGTTGATTCAACAGCACCATT & & $10,697-10,723$ & 3'-UTR \\
\hline
\end{tabular}

$a$ : nucleotide numbering refers to DENV2 full-length genome (GeneBank accession JX669481). RsrI restriction site was marked in bold type. T7 RNA polymerase promoter sequence was marked in italic and a single $\mathrm{G}$ for initiation of transcription is underlined. Regions of homology to pSVJS01 vector shown in capitals. E: envelope; F: fragment; NS: nonstructural; UTR: untranslated region.

were then introduced into BHK-21 cells by electroporation using the ECM 830 electro cell manipulator (BTX; Harvard Apparatus). For electroporation, 2 x $10^{6} \mathrm{BHK}-$ 21 cells were trypsinised, washed twice with serum-free medium, resuspended in $100 \mu \mathrm{L}$ cytomix solution (120 $\mathrm{mM} \mathrm{KCl}, 0.15 \mathrm{mM} \mathrm{CaCl}_{2}, 10 \mathrm{mM} \mathrm{K} \mathrm{HPO}_{4} / \mathrm{KH}_{2} \mathrm{PO}_{4}, \mathrm{pH}$ 7.6, 25 mM HEPES, pH 7.6, 2.0 mM EGTA, $5.0 \mathrm{mM}$ $\mathrm{MgCl}_{2}$ ) plus $2.0 \mathrm{mM}$ of ATP and $5.0 \mathrm{mM}$ of glutathione and mixed with $5 \mu \mathrm{g}$ of the transcript. Cuvettes of $0.2 \mathrm{~cm}$ gap were used and electroporation settings were as follows: two pulses of $100 \mu \mathrm{s}$ at $1,200 \mathrm{~V}$ and $1 \mathrm{~s}$ interval. As a negative control, BHK-21 cells were transfected under the same conditions with no RNA. After electroporation, cells were allowed to recover for $10 \mathrm{~min}$ at room temperature, resuspended in complete growth medium and plated into $25 \mathrm{~cm}^{2}$ flasks.

To detect DENV2 production in BHK-21, transfected cells were analysed by IFA. Specifically, three days after electroporation cells were trypsinised from the flask and seeded on glass coverslips. Coverslips were then collected four days later (i.e., 7 days post-infection), rinsed with phosphate-buffered saline (PBS), fixed with 50\% cold acetone $(\mathrm{v} / \mathrm{v})$ in PBS for $5 \mathrm{~min}$ at $4^{\circ} \mathrm{C}$ and air-dried. Next, fixed cells were incubated with a 1:100 dilution of a polyclonal hyperimmune mouse ascitic fluid (HMAF) as the primary antibody for $1 \mathrm{~h}$ at $37^{\circ} \mathrm{C}$. The HMAF reacts against group $\mathrm{B}$ flaviviruses, including the four DENV serotypes and yellow fever virus. After incubation, the cells were rinsed twice with PBS and incubated for $1 \mathrm{~h}$ at $37^{\circ} \mathrm{C}$ with a $1: 100$ dilution of fluorescein isothiocyanate-conjugated goat anti-mouse $\mathrm{IgG}$ antibody (Sigma-Aldrich) as the secondary antibody. Cells were then rinsed twice with PBS, air-dried and mounted. A DMI4000 B inverted microscope (Leica) was used for analysis. Positive immunofluorescence was observed in infected cells (Fig. 2A) showing DENV2 production in BHK-21 cells transfected with RNA transcripts derived from pSVJS01-DENV2. Transfected, noninfected cells did not show any fluorescence (data not shown).

Virus characterisation was performed by focus-forming assay in BKH-21 cells and growth curve analysis between both viruses. For the focus-forming assay, $4 \mathrm{x}$ $10^{5}$ cells/per well were plated in six-well plates and $24 \mathrm{~h}$ later cell monolayers were incubated for $1 \mathrm{~h}$ at $37^{\circ} \mathrm{C}$ with $0.8 \mathrm{~mL}$ of serial dilutions of parental DENV2 BR-3808 (parental-DENV2) and virus derived from pSVJS01DENV2. After removing the inoculum, cells were covered with $3 \mathrm{~mL}$ of MEM overlay medium (containing $2 \%$ carboxymethyl cellulose, $5 \%$ FBS and $1 \%$ antibiotic solution) and incubated at $37^{\circ} \mathrm{C}$ with $5 \% \mathrm{CO}_{2}$ for five days. Next, overlay medium was removed and the cells were fixed with $30 \%$ cold acetone (v/v) in PBS for $13 \mathrm{~min}$ at $4^{\circ} \mathrm{C}$ and washed once with PBS. Fixed cells were incubated for $1 \mathrm{~h}$ at $37^{\circ} \mathrm{C}$ with primary anti-DENV2 monoclonal antibody D1-4G2-4-15 (HB112 - ATCC) diluted $1: 2$ in ligation buffer $(0.5 \mathrm{M} \mathrm{NaCl}$ and $0.01 \%$ Tween- 20 in PBS). Cells were rinsed with wash buffer $(0.05 \%$ Tween20 in PBS) and incubated for $1 \mathrm{~h}$ at $37^{\circ} \mathrm{C}$ with horseradish peroxidase-conjugated recombinant protein $\mathrm{G}$ (Invitrogen) diluted 1:500 in ligation buffer. Three additional washing steps were performed and foci were developed by adding 3-amino-9-ethylcarbazole substrate buffer. In these assays, foci were visible at up to the $10^{-5}$ dilution for DENV2 derived from pSVJS01-DENV2. Moreover, foci of pSVJS01-derived DENV2 virus did not differ in formation or size from parental-DENV2 (Fig. 2B). These results show the production of functional and infectious DENV2 from the infectious clones. 

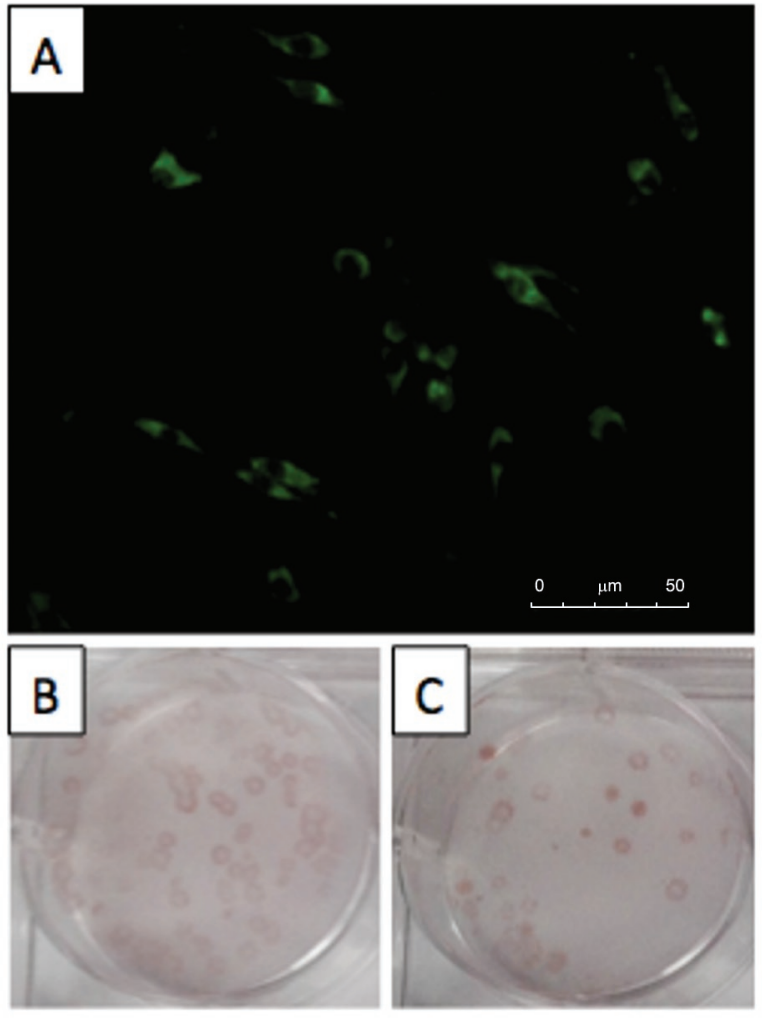

Fig. 2: in vitro characterisation of pSVJS01-DENV2 virus. A: detection of dengue virus serotype 2 (DENV2) in baby hamster kidney (BHK)-21 cells transfected with RNA derived from pSVJS01-DENV2 clone 10 by indirect immunofluorescence assay. Cells were collected at five days post-transfection and labelled with anti-flavivirus group $\mathrm{B}$ as the primary antibody and anti-mouse IgG-fluorescein isothiocyanate as the secondary antibody; B, C: plaque phenotypes of the wild type DENV2 (BR-3808) and the virus derived from pSVJS01DENV2. BHK-21 cells were infected with the different viruses for five days at $37^{\circ} \mathrm{C}$. Plaque formation was revealed by immunoperoxidase assay; B: DENV2 BR-3808; C: pSVJS01-DENV2 clone 10.

For the growth curve analysis, BHK-21 cells were seeded in 24-well plates at $6 \times 10^{4}$ cells/well and were infected $24 \mathrm{~h}$ later with both viruses at a multiplicity of infection of 0.1. The supernatant was collected from the wells at the following time-points: $0 \mathrm{~h}, 24 \mathrm{~h}, 48 \mathrm{~h}$ and $72 \mathrm{~h}$. Viral RNA was extracted from the material with the QIAamp Viral RNA Mini Kit (Qiagen). To quantify the viral genome in this material, quantitative real-time PCR was performed with the QuantiTect SYBR Green RT-PCR Kit (Qiagen), as described by Carvalho-Leandro et al. (2012). Briefly, primers that amplify a $104 \mathrm{bp}$ region of the DENV NS5 according to Kong et al. (2006) were used. PCR reactions were performed with a fixed amount of RNA and $0.4 \mu \mathrm{M}$ of each primer. Reaction conditions were as follows: $50^{\circ} \mathrm{C}$ for $30 \mathrm{~min}$, to allow reverse transcription, $95^{\circ} \mathrm{C}$ for $15 \mathrm{~min}$, to activate Taq, and 35 cycles of $94^{\circ} \mathrm{C}$ for $15 \mathrm{~s}, 60^{\circ} \mathrm{C}$ for $30 \mathrm{~s}$ and $72^{\circ} \mathrm{C}$ for 30 $\mathrm{s}$. The amount of viral RNA in each sample was calculated by cycle threshold values from the standard curve in- cluded in each PCR plate. This curve consisted of known concentrations of purified NS5 transcript, as described in Kong et al. (2006). The negative controls consisted of one reaction with no RNA template and one reaction with RNA extracted from noninfected cells. The positive control was RNA extracted from a known DENV2 infected-culture. Reactions were performed in duplicate using the Applied Biosystems 7500 fast and Real-Time PCR System. Similar results were observed between samples of cultures infected with either DENV2 BR3808 or the infectious clone-derived DENV2 at the different time-points assayed. The amounts of viral RNA at $0 \mathrm{~h}, 24 \mathrm{~h}, 48 \mathrm{~h}$ and $72 \mathrm{~h}$ were 15.6, 16.8, 17.5 and 18.0, respectively, for the BR-3808, and 15.6, 17.1, 17.1 and 17.7 RNA molecules/ $\mu \mathrm{L}\left(\log _{10}\right)$ for the pSVJS01-derived DENV2 (Fig. 3). These results also show the similar phenotype between the viruses.

Finally, the gene coding for the envelope protein, which is approximately $1,500 \mathrm{bp}$, was sequenced from both viruses using the Sanger method. The results showed that the sequences were $100 \%$ identical (data not shown), demonstrating that at least in this part of the genome no mutations arose from the strategy described here. In addition, any mutation in other genome regions that may have occurred was not enough to cause significant phenotypic differences among the parental and infectious clone-derived viruses.

The availability of DENV full-length cDNA clones that correspond to the original DENV genome is an invaluable tool for several types of study, including those on the development of attenuated or chimeric vaccines and on host-virus interactions. Furthermore, the importance of low passage DENV infectious clones should be highlighted, as these may harbour critical and unique strain-specific viral components from field-circulating isolates; hence, the importance of reporting the construction and availability of such clones.

Full-length clones have been reported for all four DENV serotypes. However, only a remarkably small amount of these are based on low passage isolates (Table II). Although there is a higher number of available

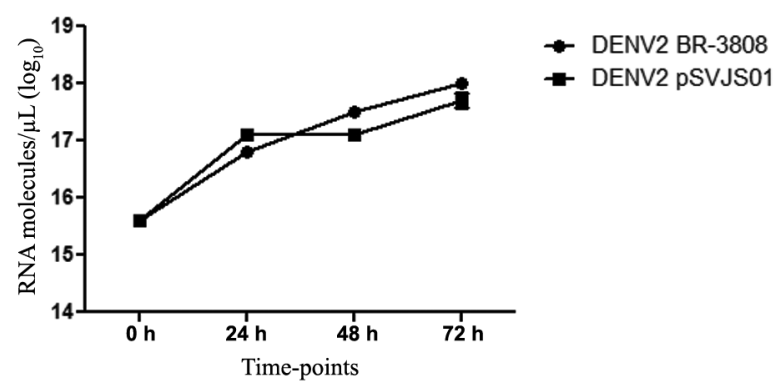

Fig. 3: growth curve analysis of parental (BR-3808) and infectious clone-derived dengue virus serotype 2 (DENV2) (pSVJS01) assessed by quantitative real-time polymerase chain reaction. Viral RNA was quantified in baby hamster kidney-21 cells infected with either viruses at $0 \mathrm{~h}, 24 \mathrm{~h}, 48 \mathrm{~h}$ and $72 \mathrm{~h}$ post-infection. 


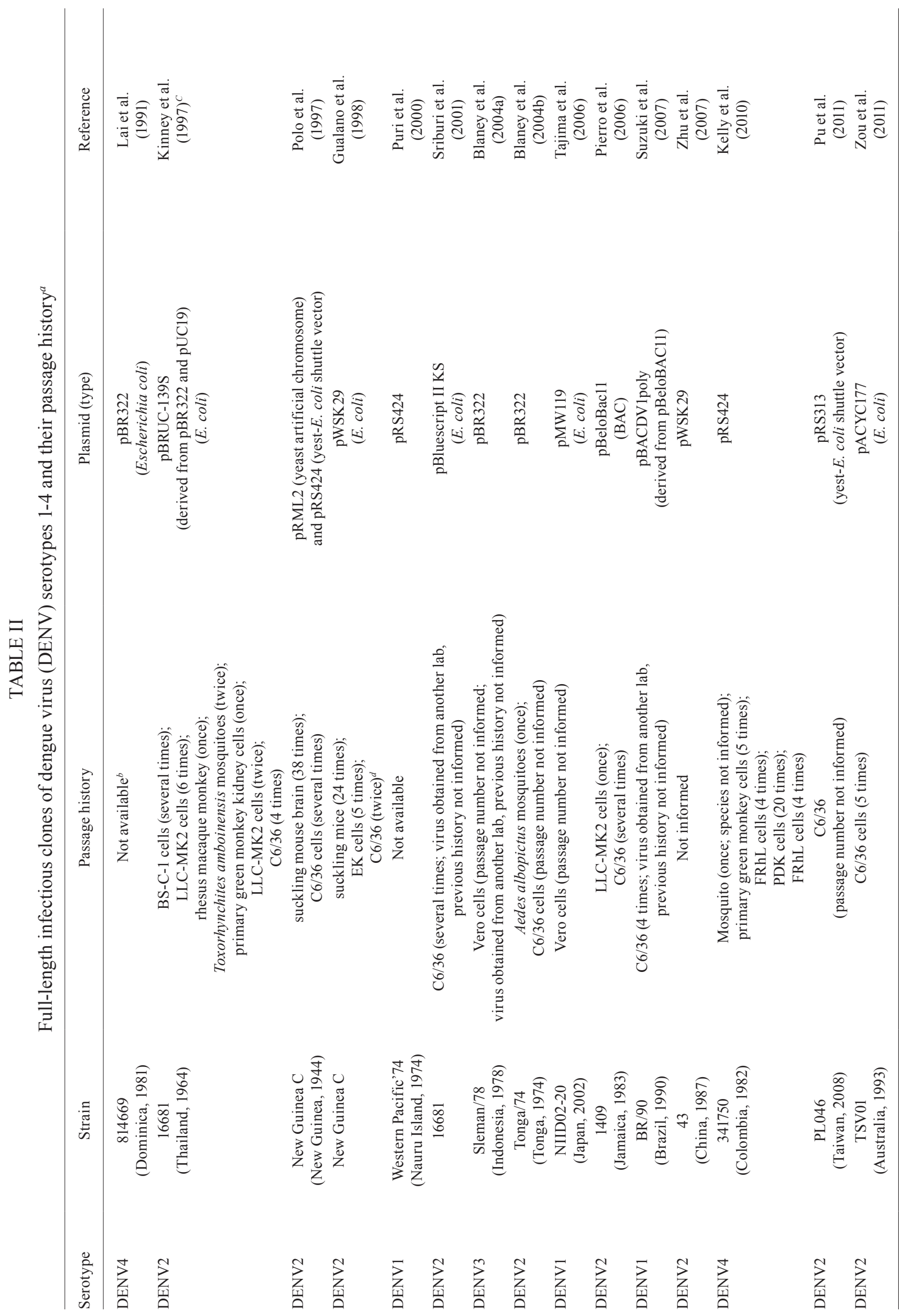




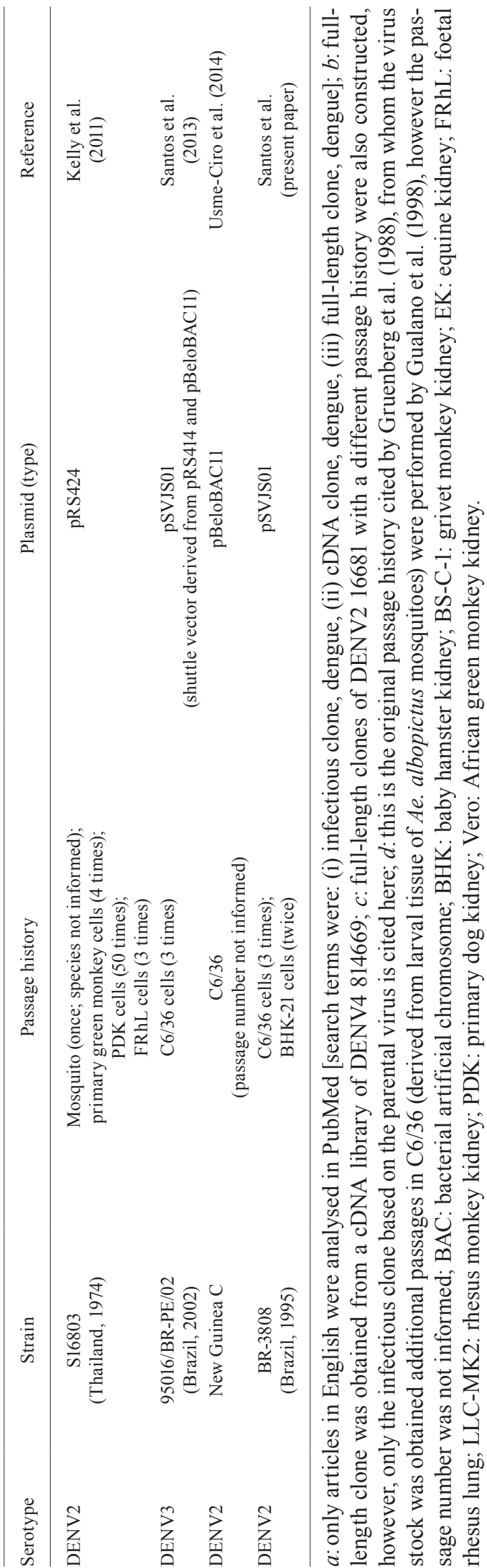

full-length DENV2 clones compared to the other three serotypes, out of the 12 full-length clones found in the literature search performed here, only a few provide the passage history of the virus and only one is reported to have been passaged under five times (Table II). The importance of full-length infectious clones based on low passage viruses is a result of mutations that arise upon sequential passages in biological systems (Lee et al. 1997, Vasilakis et al. 2009), where only low passage viruses most closely resemble the original genotypic and phenotypic features of the parental virus population.

The successful construction of a Brazilian low passage DENV2 full-length clone through homologous recombination reported here supports the use of a strategy that has been shown to be highly useful by our group for the development of flavivirus infectious clones and replicons (Queiroz et al. 2013, Santos et al. 2013).

\section{REFERENCES}

Bhatt S, Gething PW, Brady OJ, Messina JP, Farlow AW, Moyes CL, Drake JM, Brownstein JS, Hoen AG, Sankoh O, Myers MF, George DB, Jaenisch T, Wint GR, Simmons CP, Scott TW, Farrar JJ, Hay SI 2013. The global distribution and burden of dengue. Nature 496: 504-507.

Blaney Jr JE, Hanson CT, Firestone CY, Hanley KA, Murphy BR, Whitehead SS 2004a. Genetically modified, live attenuated dengue virus type 3 vaccine candidates. Am J Trop Med Hyg 71: 811-821.

Blaney Jr JE, Hanson CT, Hanley KA, Murphy BR, Whitehead SS 2004b. Vaccine candidates derived from a novel infectious cDNA clone of an American genotype dengue virus type 2. BMC Infect Dis 4: 39.

Bredenbeek PJ, Kooi EA, Lindenbach B, Huijkman N, Rice CM, Spaan WJ 2003. A stable full-length yellow fever virus cDNA clone and the role of conserved RNA elements in flavivirus replication. J Gen Virol 84: 1261-1268.

Carvalho-Leandro D, Ayres CF, Guedes DR, Suesdek L, Melo-Santos MA, Oliveira CF, Cordeiro MT, Regis LN, Marques ET, Gil LH, Magalhaes T 2012. Immune transcript variations among Aedes aegypti populations with distinct susceptibility to dengue virus serotype 2. Acta Trop 124: 113-119.

Chambers TJ, Hahn CS, Galler R, Rice CM 1990. Flavivirus genome organization, expression and replication. Annu Rev Microbiol 44: 649-688.

Chen R, Vasilakis N 2011. Dengue - quo tu et quo vadis? Viruses 3: 1562-1608.

Gibson DG 2009. Synthesis of DNA fragments in yeast by one-step assembly of overlapping oligonucleotides. Nucleic Acids Res 37: 6984-6990.

Gruenberg A, Woo WS, Biedrzycka A, Wright PJ 1988. Partial nucleotide sequence and deduced amino acid sequence of the structural proteins of dengue virus type 2, New Guinea C and PUO-218 strains. J Gen Virol 69 6: 1391-1398.

Gualano RC, Pryor MJ, Cauchi MR, Wright PJ, Davidson AD 1998. Identification of a major determinant of mouse neurovirulence of dengue virus type 2 using stably cloned genomic-length cDNA. $J$ Gen Virol 79 3: 437-446.

Horstick O, Martinez E, Guzman MG, Martin JL, Ranzinger SR 2015. WHO dengue case classification 2009 and its usefulness in practice: an expert consensus in the Americas. Pathog Glob Health 109: 19-25. 
Ishikawa T, Yamanaka A, Konishi E 2014. A review of successful flavivirus vaccines and the problems with those flaviviruses for which vaccines are not yet available. Vaccine 32: 1326-1337.

Kelly EP, Polo S, Sun W, Falgout B 2011. Evolution of attenuating mutations in dengue-2 strain S16803 PDK50 vaccine and comparison of growth kinetics with parent virus. Virus Genes 43: 18-26.

Kelly EP, Puri B, Sun W, Falgout B 2010. Identification of mutations in a candidate dengue 4 vaccine strain 341750 PDK20 and construction of a full-length cDNA clone of the PDK20 vaccine candidate. Vaccine 28: 3030-3037.

Kinney RM, Butrapet S, Chang GJ, Tsuchiya KR, Roehrig JT, Bhamarapravati N, Gubler DJ 1997. Construction of infectious cDNA clones for dengue 2 virus: strain 16681 and its attenuated vaccine derivative, strain PDK-53. Virology 230: 300-308.

Kong YY, Thay CH, Tin TC, Devi S 2006. Rapid detection, serotyping and quantitation of dengue viruses by TaqMan real-time onestep RT-PCR. J Virol Methods 138: 123-130.

Lai CJ, Zhao BT, Hori H, Bray M 1991. Infectious RNA transcribed from stably cloned full-length cDNA of dengue type 4 virus. Proc Natl Acad Sci USA 88: 5139-5143.

Lanciotti RS, Calisher CH, Gubler DJ, Chang GJ, Vorndam AV 1992. Rapid detection and typing of dengue viruses from clinical samples by using reverse transcriptase-polymerase chain reaction. $J$ Clin Microbiol 30: 545-551.

Lee E, Weir RC, Dalgarno L 1997. Changes in the dengue virus major envelope protein on passaging and their localization on the threedimensional structure of the protein. Virology 232: 281-290.

Nene V, Wortman JR, Lawson D, Haas B, Kodira C, Tu ZJ, Loftus B, Xi Z, Megy K, Grabherr M, Ren Q, Zdobnov EM, Lobo NF, Campbell KS, Brown SE, Bonaldo MF, Zhu J, Sinkins SP, Hogenkamp DG, Amedeo P, Arensburger P, Atkinson PW, Bidwell S, Biedler J, Birney E, Bruggner RV, Costas J, Coy MR, Crabtree J, Crawford M, Debruyn B, Decaprio D, Eiglmeier K, Eisenstadt E, El-Dorry H, Gelbart WM, Gomes SL, Hammond M, Hannick LI, Hogan JR, Holmes MH, Jaffe D, Johnston JS, Kennedy RC, Koo H, Kravitz S, Kriventseva EV, Kulp D, Labutti K, Lee E, Li S, Lovin DD, Mao C, Mauceli E, Menck CF, Miller JR, Montgomery P, Mori A, Nascimento AL, Naveira HF, Nusbaum C, O'Leary S, Orvis J, Pertea M, Quesneville H, Reidenbach KR, Rogers YH, Roth CW, Schneider JR, Schatz M, Shumway M, Stanke M, Stinson EO, Tubio JM, Vanzee JP, Verjovski-Almeida S, Werner D, White O, Wyder S, Zeng Q, Zhao Q, Zhao Y, Hill CA, Raikhel AS, Soares MB, Knudson DL, Lee NH, Galagan J, Salzberg SL, Paulsen IT, Dimopoulos G, Collins FH, Birren B, Fraser-Liggett CM, Severson DW 2007. Genome sequence of Aedes aegypti, a major arbovirus vector. Science 316: 1718-1723.

Pierro DJ, Salazar MI, Beaty BJ, Olson KE 2006. Infectious clone construction of dengue virus type 2, strain Jamaican 1409, and characterization of a conditional E6 mutation. J Gen Virol 87: 2263-2268.
Polo S, Ketner G, Levis R, Falgout B 1997. Infectious RNA transcripts from full-length dengue virus type 2 cDNA clones made in yeast. J Virol 71: 5366-5374.

Pu SY, Wu RH, Yang CC, Jao TM, Tsai MH, Wang JC, Lin HM, Chao YS, Yueh A 2011. Successful propagation of flavivirus infectious cDNAs by a novel method to reduce the cryptic bacterial promoter activity of virus genomes. J Virol 85: 2927-2941.

Puri B, Polo S, Hayes CG, Falgout B 2000. Construction of a full length infectious clone for dengue-1 virus Western Pacific,74 strain. Virus Genes 20: 57-63.

Queiroz SR, Silva AN, Santos JJ, Marques Jr ET, Bertani GR, Gil LH 2013. Construction of yellow fever virus subgenomic replicons by yeast-based homologous recombination cloning technique. $A n$ Acad Bras Cienc 85: 159-168.

Rico-Hesse R 2007. Dengue virus evolution and virulence models. Clin Infect Dis 44: 1462-1466.

Ruggli N, Rice CM 1999. Functional cDNA clones of the Flaviviridae: strategies and applications. Adv Virus Res 53: 183-207.

Santos JJS, Cordeiro MT, Bertani GR, Marques ETA, Gil LHVG 2013. Construction and characterisation of a complete reverse genetics system of dengue virus type 3. Mem Inst Oswaldo Cruz 108: 983-991.

Sriburi R, Keelapang P, Duangchinda T, Pruksakorn S, Maneekarn N, Malasit P, Sittisombut N 2001. Construction of infectious dengue 2 virus cDNA clones using high copy number plasmid. $J$ Virol Methods 92: 71-82.

Suzuki R, de Borba L, Duarte dos Santos CN, Mason PW 2007. Construction of an infectious cDNA clone for a Brazilian prototype strain of dengue virus type 1: characterization of a temperaturesensitive mutation in NS1. Virology 362: 374-383.

Tajima S, Nukui Y, Ito M, Takasaki T, Kurane I 2006. Nineteen nucleotides in the variable region of 3' non-translated region are dispensable for the replication of dengue type 1 virus in vitro. Virus Res 116: 38-44.

Usme-Ciro JA, Lopera JA, Enjuanes L, Almazan F, Gallego-Gomez JC 2014. Development of a novel DNA-launched dengue virus type 2 infectious clone assembled in a bacterial artificial chromosome. Virus Res 180: 12-22.

Vasilakis N, Deardorff ER, Kenney JL, Rossi SL, Hanley KA, Weaver SC 2009. Mosquitoes put the brake on arbovirus evolution: experimental evolution reveals slower mutation accumulation in mosquito than vertebrate cells. PLoS Pathog 5: e1000467.

Zhu W, Qin C, Chen S, Jiang T, Yu M, Yu X, Qin E 2007. Attenuated dengue 2 viruses with deletions in capsid protein derived from an infectious full-length cDNA clone. Virus Res 126: 226-232.

Zou G, Chen YL, Dong H, Lim CC, Yap LJ, Yau YH, Shochat SG, Lescar J, Shi PY 2011. Functional analysis of two cavities in flavivirus NS5 polymerase. J Biol Chem 286: 14362-14372. 